\title{
Ocular Involvement in Mantle Cell Lymphoma Detected by F I8 FDG PET/CT
}

\author{
Mantle Hücreli Lenfomada FI 8-FDG PET/BT ile Saptanan Göz Tutulumu
}

\author{
Elgin Özkan, Seda Laçin, Çiğdem Soydal, Mine Araz, N. Özlem Küçük \\ Ankara University, Faculty of Medicine, Department of Nuclear Medicine, Ankara, Turkey
}

\begin{abstract}
Mantle Cell Lymphoma (MCL) is an uncommon but aggressive form of non-Hodgkin's lymphoma. The extranodal involvement is not unusual especially in bone marrow, spleen, gastrointestinal tract and Waldeyer's ring. Ocular involvement is very exceptional and the most commonly affected site is the orbit $(90 \%)$, followed by the lacrimal gland (50\%) and the eyelids (50\%). Today, PET/CT is widely used in non-Hodgkin's lenfoma especially in staging and evaluation of treatment response. Authors report MCL with ocular involvement that was detected on PET/CT scan. (MIRT 201 1; 20: 36-7) Key words: Lymphoma, non-Hodgkin; positron-emission tomography; eyelid disease

Özet

Mantle Hücreli Lenfoma (MHL), Hodgkin dıșı lenfomanın nadir ancak agresif bir formudur Ekstranodal tutulum nadir değildir ve özellikle kemik iliğinde, dalakta, gastrointestinal sistemde ve Waldeyer halkasında izlenir. Göz tutulumu ise oldukça nadir olup, izlendiğinde en sık etkilenen bölgeler sırasıyla orbita (\%90), lakrimal bez (\%50) ve göz kapaklarıdır (\%50). Günümüzde PET/BT, Hodgkin dıșı lenfomada özellikle evreleme ve tedaviye yanıı değerlendirmede yaygın olarak kullanılmaktadır. Biz bu olguda göz kapağı tutulumu ile seyreden $\mathrm{MCL}$ olgusunda PET/BT bulgularını sunduk. (MIRT 201 1; 20: 36-7)

Anahtar kelimeler: Lenfoma, non-Hodgkin, pozitron emisyon tomografisi, göz kapağı hastalıkları
\end{abstract}

\section{Case Report}

Mantle Cell Lymphoma (MCL) has been diagnosed with scalene lymph node biopsy in a 63-year-old woman. At the time of diagnosis, the disease was at stage $4 \mathrm{~B}$ with mediastinal, cervical, hilar, abdominal lymph nodes which were detected by CT (computerized tomography). There was also bone marrow involvement. She received chemotherapy and complete response was confirmed with control CT scans. The first PET/CT scan performed at this period was normal. She has been followed up disease free for about six months. Then she complained about cervical mass and bilateral eyelid swelling. Regarding to second PET/CT findings which was performed for restaging, she received chemotherapy again for the relapse in the cervical, mediastinal, hilar, abdominopelvic and inguinal lymph nodes. A slight FDG uptake was also seen at both eyelids on this second PET/CT. She was followed for a period of time without any medical treatment in accordance with the patient's request. Eight months later an inguinal lymph node was recognized and excisional biopsy revealed recurrence. She received of chemotherapy again and then third $\mathrm{PET} / \mathrm{CT}$ was performed for restaging of the disease. In the maximum intensity projection (MIP) image of whole body, in the third PET/CT scan (Figure 1) showed pathological FDG uptake at multiple lymph nodes in the head and neck, chest, abdomen and inguinal regions, and diffusely in the stomach. Axial image of the orbita in the first PET/CT image showed no pathological ocular FDG uptake (Figure 2). After about 2 


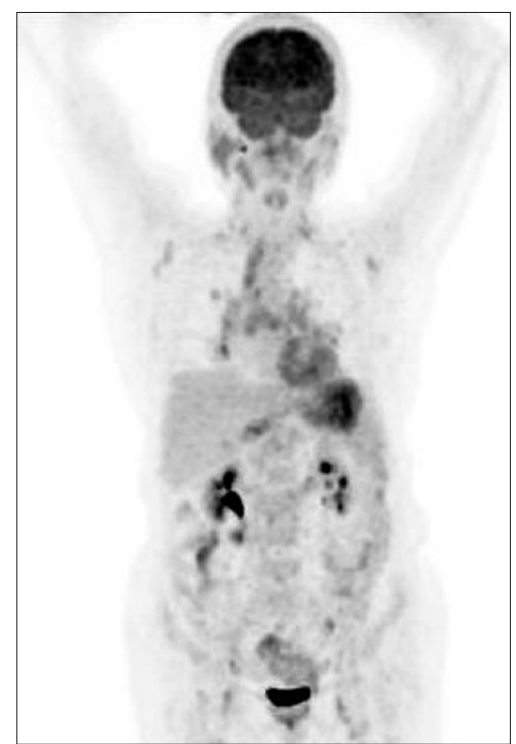

Figure 1. Maximum intensity projection (MIP) image of whole body in the third PET/CT scan. Pathological FDG uptake was seen at multiple lymph nodes in the head and neck, chest, abdomen and inguinal regions, and in the stomach

years, however, axial image of orbita in third PET/CT represented diffuse FDG uptake at both eyelids (Figure 3), significantly different from the first scan. There may be a physiological uptake at the extraocular muscles, but in this case, comparison of first and third PET/CT scan showed that the FDG uptake in the muscles can be easily recognized as pathological with increase in thickness of the muscles in CT (1).

$\mathrm{MCL}$ is an uncommon but aggressive form of non-Hodgkin's lymphoma. The extranodal involvement is not unusual, especially in bone marrow, spleen, gastrointestinal tract and Waldeyer's ring (2,3). Such localizations (breast, ocular adnexal region, skin etc.) are exceptional in $\mathrm{MCL}(4)$. The most commonly affected site of ocular involvement is the orbit (90\%), followed by the lacrimal gland (50\%) and the eyelids $(50 \%)(5,6)$. MCL presenting in the ocular adnexal region has a male predominance and is associated with stage III/IV disease. Our stage IV patient did not have any ocular symptoms at diagnosis, however as the disease proceeded, severe eyelid edema occurred showing diffuse spread of the disease supported by PET/CT findings. We report an uncommon case with MCL; ocular involvement that was detected on PET/CT

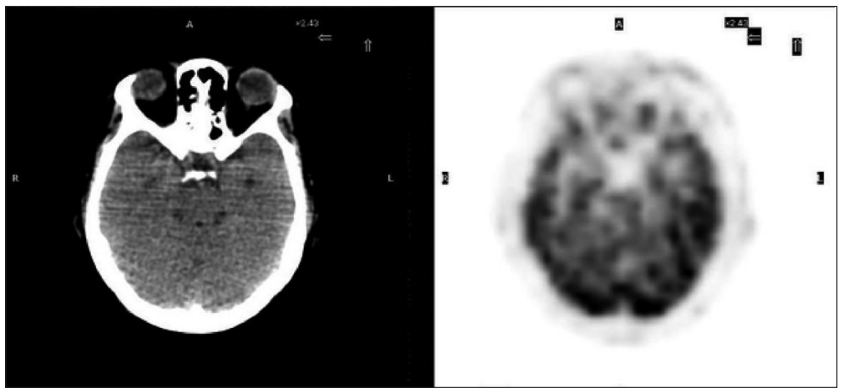

Figure 2. Axial CT and PET images of the orbita in the first PET/CT scan

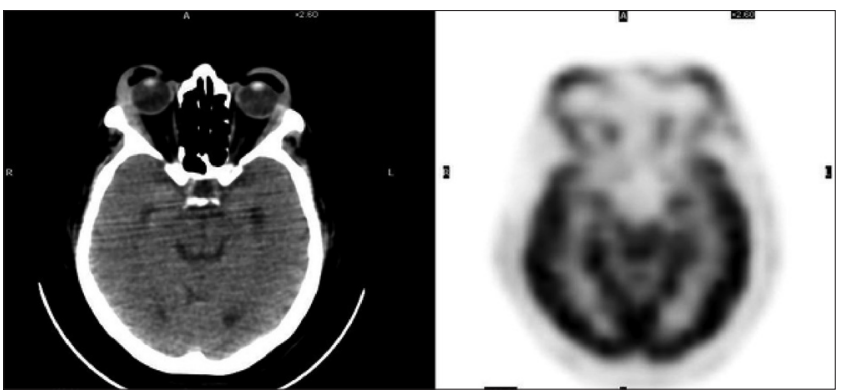

Figure 3. Axial CT and PET images of the orbita in the third PET/CT scan

scan. This case reveals the need of total body PET/CT imaging in patients with aggressive non-Hodgkin's lymphoma in order not to miss an exceptional involvement.

\section{References}

1. Valenzuela AA, Allen C, Grimes D, Wong D, Sullivan TJ. Positron Emission Tomography in the Detection and Staging of Ocular Adnexal Lymphoproliferative Disease. Ophthalmology 2006;1 13:2331-2337.

2. Argatoff LH, Connors JM, Klasa RJ, Horsman DE, Gascoyne RD. Mantle cell lymphoma: a clinicopathologic study of 80 cases. Blood 1997; 15:2067-2078.

3. Bosch F, López-Guillermo A, Campo E, Ribera JM, Conde E, Piris MA, Vallespí T, Woessner S, Montserrat E. Mantle cell lymphoma: presenting features, response to therapy, and prognostic factors. Cancer 1998; 1:567-575.

4. Boullanger N, Renou P, Dugay J, Boyer J, de Yberlucea LR, Combe $M$, Coulon MA. Palpable mantle cell lymphoma in the breast. Presse Med 2001;30:163-165.

5. Rasmussen P, Siö LD, Prause JU, Ralfkiaer E, Heegaard S. Mantle cell Lymphoma in the orbital and adnexal region. $\mathrm{Br} \mathrm{J}$ Ophthalmol 2009;93:1047-1051

6. Looi A, Gascoyne RD, Chhanabhai M, Connors JM, Rootman J, White VA. Mantle cell Lymphoma in the ocular adnexal region. Ophthalmology 2005;1 12:114-119. 